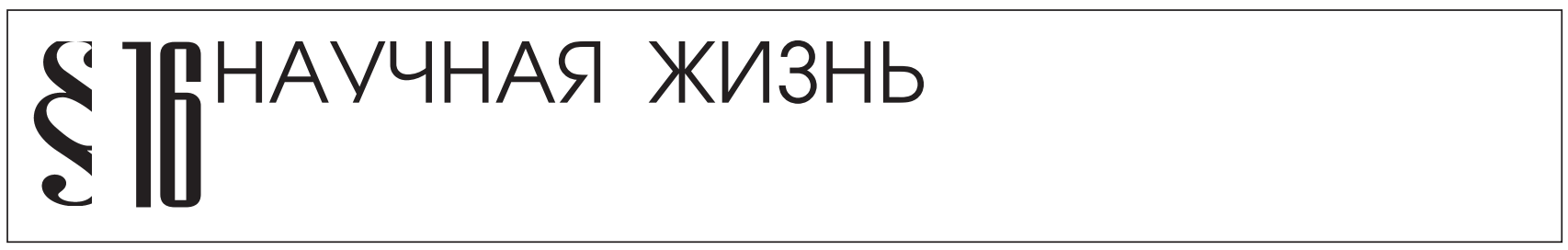

Рёрихт А.А.

\title{
ЮСТИЦИЯ КАК ПРЕИМУЩЕСТВО ДЛЯ ЭКОНОМИКИ: МЕЖДУ ОЖИДАНИЕМ И РЕАЛЬНОСТЬЮ (ПОЗИЦИИ ГЕРМАНСКИХ ПРАВОВЕДОВ)
}

Аннотация: В статье представлены основные итоги дискуссии о роли юстиции, особенно судебной системь и судей, в Германии на современном этапе развития общества и государства в обеспечении не только законности и правопорядка в иелом, но и в сфере экономики. Отмечаются указанные участниками обсуждения недостатки функционирования немецккй судебной системы и ее кадрового обеспечения; прогрессирующее усложнение материальных и процессуальных правовых норм и увеличение их объема; слабое информирование общественности о задачах и возможностях современного суда, трудностях, возникающих у судей и при рассмотрении гражданских, трудовых и иных споров. Эти и другие моменты хотя и несколько снижают эффективность юстиции, но принципиально не колеблют ее высокого значения, поскольку в целом суды и судьи Германии характеризуются высоким профессионализмом, стабильной независимостью, чрезвычайно низкой склонностью к коррупции. В заключение отражены позиции практиков по вопросу о путях и мерах совершенствования судебной деятельности и преодолении дисбаланса между ожидаемыми от юстиции и реальностью ее функционирования для экономики. Ключевые слова: Коррупция, право, суд, судопроизводство, судебная система, судьи, трудовые споры, юстиция, экономика, адвокат.

Abstract: This article presents some of the main results of a discussion on the role of justice, especially the legal system and the judges in Germany at the current stage of development of the society and the state with regards to not only law and order as a whole, but also in area of economy. The author highlights the statements made by the participants of the discussion on the flaws in the functioning of the German judicial system and its staff; the worsening of the material and procedural legal norms and the increase of their volume; the lack of public informing on the tasks and abilities of the modern courts, and the difficulties that the judges are faced with when they review civil, labor, or other cases. These and other elements, although somewhat lower the effectiveness of the legal system, do not take away from its importance, as German courts and judges are synonymous with high professionalism, independence and an extremely low chance of corruption. In the conclusion, the author reflects the positions of the experts on the ways and measures of improving the judicial system and defining the balance between the expectations and the reality of its function with regards to economy. Keywords: Corruption, law, court, court proceedings, judicial system, judges, labor arguments, justice, economy, lawyer.

бсуждение практиками, в первую очередь судьями, адвокатами, представителями бизнессообщества и учеными - юристами и экономистами проблемы, обозначенной названием «Юстиция как преимущество для экономики: между ожиданием и реальностью» являлось частью цикла встреч «Юстиция в диалоге», проходящих в течение полугода по всей Германии. Организаторами данной встречи, состоявшейся 25 сентября 2014 г. в Гамбурге в Частной школе права Буцериус являются Немецкий Союз Судей, Гамбургское объединение Судей и Объединение «Правовое Месторасположение Гамбург». Она состояла из трех частей: дебатов на подиуме между представите- лями экономики и юстиции; их дискуссии с публикой и завершающей речи адвоката, подводящего итоги и высказывающего свои ожидания к судебной системе.

На подиуме присутствовали Кристиан Граф-руководитель Торговой Палаты г. Гамбурга, руководитель отдела «Право и Fair Play», которому также доверили вступительную речь; Биргит Гантц-Ратманн - бывшая председатель кадрового и правового отдела в Немецкой железной дороге - ДБ Карго, бывшая судья, ныне омбудсман немецкой железнодорожной компании; д-р права Марк Тулли - знаменитый судья, председательствующий в Гамбургском Верховном Земельном Суде, Председатель Гамбургского Объединения Судей; 
Фридрих-Йоахим Мемель - Президент Гамбургского Верховного административного Суда и председатель объединения «Правовое Месторасположение Гамбург».

Заключительное слово было предоставлено адвокату, президенту Палаты адвокатов Гамбурга Отмару Кури.

Вел дискуссию проф. Др. Йоахим Ян, редактор экономического раздела газеты Франкфуртская Общая Газета (основной и самой серьезной газеты Германии).

После короткого приветствия со стороны организаторов, в котором указывалось на то, что Германия занимает третье место в мире по качеству судебной системы, но останавливаться на этом не следует, так как, несмотря на все плюсы, имеются и отдельные проблемы, рассмотрению которых и посвящены данные встречи, вступительную речь от лица экономики, и в особенности предприятий среднего класса, произнес Кристиан Граф.

Он начал с того, что для экономики важны особо гражданское производство судов общей юрисдикции, а также производство в трудовых судах, в Германии образующих отдельную ветвь судебной системы ${ }^{1}$. Преимущество функционирующей надлежащим образом судебной системы, сказал он, является принципиальным для Германии и объясняется крайне низким уровнем коррупции, низкими судебными расходами, доверием граждан к судьям и иным актерам юстициарного аппарата. Однако представления представителей бизнеса о судебной системе омрачены одной большой проблемой - это сроки, а точнее - длительность рассмотрения дел и, соответственно, связанные с этим косвенные расходы. В Земельном суде в первой инстанции дела рассматриваются в среднем 9 месяцев, в Верховном Земельном Суде - 12 месяцев. У представителей немецкой экономики поэтому возникает субъективное ощущение, что это слишком долго. При этом К. Граф подчеркнул, однако, что субъективно как слишком продолжительный люди воспринимают любой процесс и с этим ощущением сложно что-либо сделать. Тем более важной становится коммуникация судебной системы с общественностью. Без этого общественность не сможет понять нужды, потребности и механизмы работы юстиции.

Помимо этого, К. Граф говорил о конкуренции судебной системы с другими отраслями за ресурсы при торможении дальнейших задолженностей на федеральном бюджетном уровне.

Он также обозначил проблему уменьшения числа гражданских дел в судах общей юрисдикции, приводя

${ }^{1}$ См.: Жалинский А.Э., Рёрихт А.А. Введение в немецкое право. М.: Спарк, 2001. цифры, говорящие о том, что по определенным категориям дел стали подавать на $30 \%$ меньше исков. Данные цифры были однако оспорены публикой, состоявшей в основном из судей и небольшого числа представителей научной общественности, во время дискуссии.

В заключение своей речи Кристиан Граф сказал, что в целом судебная система работает хорошо, особенно в сравнении с другими странами , но дальнейшее научное изучение судейского права и судебной системы необходимо, также как и улучшение коммуникаций между судами и гражданами.

Далее слово передали Марку Тулли, который начал с нетипичной для немецкого официального лица метафоры о канализации, которая когда работает, никого не беспокоит, а когда барахлит, начинает пованивать и если затор быстро не убрать, легкая вонь перерастает в огромную структуральную проблему.

Он назвал одной из основных проблем судебной системы постоянно растущую сложность материального права и процессуальных норм, что периодически приводит к ослаблению внимания к собственно классическим процессам нахождения правовой истины. Он также согласился с К. Графом по поводу недостаточности ресурсов и недостаточности коммуникаций. Наряду с этим М. Тулли отметил, что суды должны объяснять общественности свои потребности и также тот факт, что работающая судебная система не может ничего не стоить. В итоге он пришел к заключению, что в Германии судебная система обходится в месяц каждому гражданину не дороже одной пиццы, что на самом деле недорого.

Затем выступила Биргит Гантц-Ратманн, рассматривающая образование и дополнительную квалификацию как основные проблемы судейского сообщества. Она также говорила о том, насколько для характера судьи может быть опасно десятилетиями иметь право решать за других и субъективное отношение к судейской независимости. Она призвала судей, несмотря на независимость, смотреть на мир раскрытыми глазами, а также отметила недостаточность технического оснащения судов, которое однако тут же оспорил следующий оратор - Фридрих-Йоахим Мемель.

В своем докладе он поставил вопрос о том, как должны подавать себя судьи, чтобы общественность поняла, насколько хорошо они работают. Он сформулировал тезис, что общество является лишь настолько сильным насколько оно может доказать, что оно справляется с конфликтными ситуациями. При этом Ф.-Й. Мемель отметил важность для экономики не только судов общей юрисдикции и трудовых судов, но и ад- 


\section{Право и политика $3(183) \cdot 2015$}

министративных и финансовых. Почему-то никто из присутствующих ни разу не упомянул торговые суды, хотя, казалось бы, они также важны для экономики. Он сказал, что судебная система должна доказывать обществу чего она стоит.

Самыми важными факторами продуктивности судебной системы Ф.-Й. Мемель считает кадры и их мотивацию, которую необходимо поддерживать и сохранять. Для этого необходимо разумное руководство персоналом, его распределение, проведение повышения квалификации, развитие гордости за свою профессию. Он подчеркнул, что это аспекты, которые необходимо обдумать при внутренней реформе.

Далее он предложил подумать о способе работы юстиции, которая сокращает обстоятельства дела до предмета спора, обсуждение которого приводит к решению. Но часто это решение, вынесенное подобным образом, не приводит к правовому умиротворению. Здесь также докладчик отметил необходимость перемен, например, путем внесения медиативных элементов в сам процесс, повышение квалификации всех судей в области ведения процесса. С его точки зрения, вероятно, правильной, это бы привело к повышению степени признания решений.

При этом Ф.-Й. Мемель пытался развеять опасения, состоящие в том, что медиация или третейское судопроизводство способны составить конкуренцию судебной системе. Слишком малое количество дел рассматриваются таким образом. Но при этом их следует расценивать как разумное и необходимое дополнение к судебной системе.

После этого первого круга дискуссии ведущим был задан вопрос о пожеланиях к судебной системе. Кристиан Граф ответил на это, что с точки зрения представителей среднего класса немецкой экономики судьям не хватает экономического мышления, Биргит Гантц-Ратманн отметила жесткость рамок развития судейских карьер, Марк Тулли высказался в пользу специализации судей, которая повышает доверие граждан в качество судопроизводства и привел в пример палату Гамбургского суда по делам о врачебной ответственности. Он критиковал средства массовой информации, не проводящие при передаче информации необходимой дифференциации, что, естественно при втискивании крайне сложного юридически многогранного процесса в пятнадцатисекундное сообщение. М. Тулли, далее, отметил отсутствие коррупции и посчитал это следствие хорошей социально-экономической ситуации в Германии. Ф.-Й. Мемель поддержал высказанный ранее тезис о перманентном росте правовой сложности, в особенности из- за права ЕС и дел беженцев, требующих всегда быстрых решений, что приводит к откладыванию судьями других дел и росту стопок на их столах ${ }^{2}$. Он еще раз обратился к теме необходимости коммуницировать проблемы и потребности судебной системы для общественности. В свою очередь Б. Гантц-Ратманн отметила необходимость борьбы с некачественно работающими судьями, которых обычно никто не трогает и они продолжают вести удобное существование за счет своих коллег. В связи с этим она призвала президентов судов более мужественно выполнять свои кадровые функции, а науку - пересмотреть структуры дисциплинарного права.

После этого право высказываться перешло к публике. Были затронуты следующие аспекты:

- выполнение и реализуемость судебных решений как принципиальный фактор функционирования судебной системы;

- служащие судебной системы, не являющиеся судьями как часть кадрового вопроса; жалобы на работающих на полставки матерей, усложняющих административное планирование и вызванная этим бурная реакция с тезисом о том, что на полставки работают не только матери, но и отцы, и что сочетаемость семейной жизни и работы более важна, нежели трудности административного планирования, и вообще хороший судья должен быть живущим цельным человеком;

- вопрос о том, как обязать судей воспринимать предлагаемое повышение квалификации;

- развитие коммуникативных способностей судей по разговору не только с адвокатами, но и с натуральными сторонами дела (при этом все сошлись во мнении, что немецкие судьи и в этом аспекте лучше других).

Кроме того, большего кадрового разнообразия среди судей пожелали представители адвокатского сообщества; они же указали на то, что в индексе Transparency international Германия занимает только 12-е место, а значит есть, что улучшать.

\footnotetext{
${ }^{2}$ Накануне проведения встречи юристов в Гамбурге в журнале «Шпигель» были опубликованы данные об объеме работы немецких судей и иных уполномоченных лиц по делам беженцев, об экономических затратах на рассмотрение дел, временное содержпние беженцев и т.п. В 1996 г. было подано первичных ходатайств 128000 , в 2013 г. - 130000, а с января по август 2014 г. - 110000; до конца этого года прогнозируется увеличение до 200000 (в среднем количество ходатайств, поданных в ФРГ, составляет почти треть от общего числа их в ЕС в целом). Если раньше большую часть заявителей составляли беженцы из Сербии, Македонии, Боснии-Герцеговины (около 40\%), то теперь это $16,9 \%$, а на первое место переместились беженцы из Сирии и Арабской Республики - 19,2\%. Далее следуют беженцы из Эритреи -7,2\%, Афганистана - 5,7\%, Албании - 5,2\% (См.: Hilfesuchende // Spiegel. 2014. 39 vom 22.9.2014. S- $20=22$ ).
} 
DOI: $10.7256 / 1811-9018.2015 .3 .13292$

При цитировании этой статьи сноска на доі обязательна

Научная жизнь

В целом необходимо отметить, что встреча удалась. Дебаты и выступления имели крайне высокий уровень, проводились приветливо и открыто. Российским правоведам - ученым и практикам, ко- нечно, можно только мечтать о немецких проблемах. Но лишний повод задуматься о своих российских проблемах судебной системы, учитывая их количество и качество ${ }^{3}$, не помешает.

\section{Библиография:}

1. Горбуз А.К., Краснов М.А., Мишина Е.А., Сатаров Г.А. Трансформация российской судебной власти. Опыт комплексного анализа. СПб.: Норма, 2010;

2. Жалинский А.Э. Введение в специальность «Юриспруденция»: Профессиональная деятельность юриста. 2-е изд. М.: Проспект, 2007;

3. Жалинский А.Э., Рёрихт А.А. Введение в немецкое право. М.: Спарк, 2001.

4. Лебедев В.М. Судебная власть в современной России. СПб.: СПбГУ, 2001;

5. Петрухин И.Д. Судебная власть: контроль за расследованием преступлений. М.: проспект, 2008;

6. Судебная власть / Под ред. И.Л. Петрухина. М.: Проспект, 2003

\section{References (transliterated):}

1. Gorbuz A.K., Krasnov M.A., Mishina E.A., Satarov G.A. Transformatsiya rossiiskoi sudebnoi vlasti. Opyt kompleksnogo analiza. SPb.: Norma, 2010;

2. Zhalinskii A.E. Vvedenie v spetsial'nost' «Yurisprudentsiya»: Professional'naya deyatel'nost' yurista. 2-e izd. M.: Prospekt, 2007;

3. Zhalinskii A.E., Rerikht A.A. Vvedenie v nemetskoe pravo. M.: Spark, 2001.

4. Lebedev V.M. Sudebnaya vlast'v sovremennoi Rossii. SPb.: SPbGU, 2001;

5. Petrukhin I.D. Sudebnaya vlast': kontrol' za rassledovaniem prestuplenii. M.: prospekt, 2008.

${ }^{3}$ См. об этом, например: Горбуз А.К., Краснов М.А., Мишина Е.А., Сатаров Г.А. Трансформация российской судебной власти. Опыт комплексного анализа. СПб.: Норма, 2010; Жалинский А.Э. Введение в специальность «Юриспруденция»: Профессиональная деятельность юриста. 2-е изд. М.: Проспект, 2007; Лебедев В.М. Судебная власть в современной России. СПб.: СПбГУ, 2001; Петрухин И.Д. Судебная власть: контроль за расследованием преступлений. М.: проспект, 2008; Судебная власть / Под ред. И.Л. Петрухина. М.: Проспект, 2003 и многие др. 